\title{
Triple-negative breast cancer is associated with EGFR, CK5/6 and c-KIT expression in Malaysian women
}

\author{
Shant Kishen Kanapathy Pillai ${ }^{1}$, Annie Tay ${ }^{1}$, Suseela Nair ${ }^{2}$ and Chee-Onn Leong ${ }^{3,4^{*}}$
}

\begin{abstract}
Background: Triple-negative breast cancer (TNBC) is a heterogeneous subgroup of breast cancer characterized by the lack of estrogen receptor (ER), progesterone receptor (PR) and the human epidermal growth factor receptor 2 (HER2) expressions. This subgroup of refractory disease tends to have aggressive clinical behavior, high frequency of metastasis and lack of response to current hormonal or targeted therapies. Despite numerous studies reporting the clinicopathological features of TNBC and its association with the basal-like phenotype in the Western population, only limited data are available in the Asian population. Therefore, the aim of this study was to investigate the clinicopathological characteristics of TNBC and its association with epidermal growth factor receptor (EGFR), cytokeratin 5/6 (CK5/6) and mast/stem cell growth factor receptor (C-KIT or CD117) expression in Malaysian women.
\end{abstract}

Methods: A total of 340 patients diagnosed with primary breast cancer between 2002 and 2006 in Malaysia were reviewed and analyzed.

Results: The incidence of TNBC was 12.4\% (42/340). Bivariate analysis revealed that TNBC was strongly associated with a younger age, higher grade tumor and p53 expression. Further immunohistochemical analysis suggested that TNBC in Malaysian women was strongly associated with EGFR, CK5/6 and c-KIT expression with high a Ki-67 proliferation index.

Conclusion: In conclusion, our study confirms the association of TNBC with basal-like marker expression (EGFR, CK5/6 and c-KIT) in Malaysian women, consistent with studies in other populations.

Keywords: Triple-negative breast cancers, Basal-like, EGFR, CK5/6, c-Kit

\section{Background}

The recent advances of DNA microarray technology has enabled the classification of breast cancer into subgroups based on the gene expression profile [1]. Based on the study of these profiles, breast cancer can be divided into five subtypes: luminal A, luminal B, basal-like, normal-like and human epidermal growth factor receptor 2 (HER2)overexpressing subtype [1-3]. Of particular importance is the basal-like subtype, which accounts for 15 to $20 \%$ of all breast cancers and confers a markedly poor prognosis compared to other subtypes $[1,4,5]$.

\footnotetext{
*Correspondence: cheeonn_leong@imu.edu.my

${ }^{3}$ School of Pharmacy and Health Sciences, International Medical University, Bukit Jalil, Kuala Lumpur 57000, Malaysia

${ }^{4}$ International Medical University, 126 Jalan 19/155B, Bukit Jalil, Kuala Lumpur 57000, Malaysia

Full list of author information is available at the end of the article
}

The majority of basal-like breast cancers exhibit a "triple-negative" phenotype, characterized by the lack of expression of the estrogen receptor (ER) or the progesterone receptor (PR) and a lack of HER2 amplification. They also often have a high frequency of p53 mutations $[6,7]$.

In most cases, basal-like breast cancer is conveniently defined based on the "triple-negative" phenotype. However, there is evidence that triple-negative breast cancers (TNBC) and basal-like breast cancers (BLBC) might be of two different biological entities [8-10]. Indeed, it has been reported that only $80 \%$ of the tumor that express basal-like markers (EGFR, CK5/6 and/or c-KIT) are triple-negative in a Western population [1,4,8,11-13].

Although the clinicopathologic characteristics of the basal-like carcinomas, compared with other subtypes,

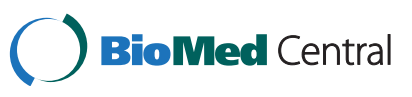


have been reported in the Korean and Singaporean populations recently $[14,15]$, the true relationship between triple-negative breast cancer and those showing basal-like expression markers has not been enunciated. Thus, our study aimed to investigate the pathology of TNBC in Malaysian women and comprehend the relationship between TNBC and BLBC in our population.

\section{Methods}

\section{Tissue and patient data}

Patients diagnosed with primary breast cancer at the Gleneagles Intan Medical Centre (GIMC), Malaysia, between 2002 and 2006 were included in the study. Clinicopathological parameters including age, tumor size, histological grade, histological subtype, associated ductal carcinoma in situ (DCIS), lymphovascular invasion and nodal status were evaluated. ER and PR statuses were determined using a standard immunohistochemistry (IHC) staining protocol on initial diagnostic material using proteinase $\mathrm{K}$ antigen retrieval method followed by mouse anti-human ER $\alpha$ monoclonal antibody (clone 1D5; DAKO, Denmark) and mouse anti-human PR monoclonal antibody (clone PgR 636; DAKO, Denmark). ER or PR positivity was defined as the presence of $1 \%$ or more positively-stained tumor cells as described previously [16,17]. HER2 expression was determined using the DAKO Herceptest ${ }^{\circledR}$ Kit (Dako, Carpinteria, CA, USA) and scored according to international guidelines [18]. HER2 scores of 0 and $1+$ were considered negative. HER2 scores of $2+$ and $3+$ were considered as HER2 overexpression [16]. All results were available from the original pathology reports except for HER2 amplification

Table 1 Summary of the clinical pathological status of triple-negative cases (TNBC) and non triple-negative cases (nonTNBC)

\begin{tabular}{|c|c|c|c|}
\hline \multirow[t]{2}{*}{ Characteristic } & \multicolumn{3}{|c|}{ No. of patients (\%) } \\
\hline & TNBC $(\mathrm{N}=42)$ & non-TNBC $(\mathrm{N}=298)$ & TOTAL \\
\hline \multicolumn{4}{|l|}{ AGE AT DIAGNOSIS (y) } \\
\hline$\leq 40$ & $15(35.7 \%)$ & $49(16.4 \%)$ & $64(18.8 \%)$ \\
\hline $41 \leq y \leq 49$ & $13(31.0 \%)$ & $113(37.9 \%)$ & $126(37.1 \%)$ \\
\hline $50 \leq y \leq 65$ & $13(31.0 \%)$ & 107 (35.9\%) & $120(35.3 \%)$ \\
\hline$>65$ & $1(2.4 \%)$ & $29(9.7 \%)$ & $30(8.8 \%)$ \\
\hline \multicolumn{4}{|l|}{ HISTOLOGY } \\
\hline DCIS & $3(7.1 \%)$ & $35(11.7 \%)$ & $38(11.2 \%)$ \\
\hline IDC & $35(83.3 \%)$ & $232(77.9 \%)$ & $267(78.5 \%)$ \\
\hline Others & $4(9.5 \%)$ & $31(10.4 \%)$ & $35(10.3 \%)$ \\
\hline \multicolumn{4}{|l|}{ GRADE } \\
\hline 1 (well differentiated) & $0(0.0 \%)$ & $7(2.3 \%)$ & $7(2.1 \%)$ \\
\hline 2 (moderately differentiated) & $6(14.3 \%)$ & $110(36.9 \%)$ & $116(34.1 \%)$ \\
\hline 3 (poorly differentiated) & $32(76.2 \%)$ & $151(50.7 \%)$ & $183(53.8 \%)$ \\
\hline Not determined & $4(9.5 \%)$ & $30(10.1 \%)$ & $34(10.0 \%)$ \\
\hline \multicolumn{4}{|l|}{ TUMOR SIZE (cm) } \\
\hline$\leq 2$ & $12(28.6 \%)$ & $109(36.6 \%)$ & $121(35.6 \%)$ \\
\hline $2<\mathrm{cm} \leq 5$ & $15(35.7 \%)$ & 99 (33.2\%) & $114(33.5 \%)$ \\
\hline$>5$ & $3(7.1 \%)$ & $15(5.0 \%)$ & $18(5.3 \%)$ \\
\hline Not determined & $12(28.6 \%)$ & $75(25.2 \%)$ & $87(25.6 \%)$ \\
\hline \multicolumn{4}{|l|}{ LYMPH NODE INFILTRATION } \\
\hline Positive & $17(40.5 \%)$ & 91 (30.5\%) & $108(31.8 \%)$ \\
\hline Negative & $25(59.5 \%)$ & $194(65.1 \%)$ & $219(64.4 \%)$ \\
\hline Not determined & $0(0.0 \%)$ & $13(4.4 \%)$ & $13(3.8 \%)$ \\
\hline \multicolumn{4}{|l|}{ p53 STATUS } \\
\hline Positive & $15(35.7 \%)$ & $45(15.1 \%)$ & $60(17.6 \%)$ \\
\hline Negative & $27(64.3 \%)$ & $251(84.2 \%)$ & $278(81.8 \%)$ \\
\hline Not determined & $0(0.0 \%)$ & $2(0.7 \%)$ & $2(0.6 \%)$ \\
\hline
\end{tabular}


which was not determined at the time of diagnosis. Triple-negative breast cancers (TNBC) were defined as tumors that were ER, PR and HER2 negative. Non triple-negative (non-TNBC) cases were defined as tumors that express ER, PR or HER2. This study was approved by the Institutional Review Board of the International Medical University, Malaysia (IRB protocol number IMU-BMS I02/2009-2). Written informed consent for use of all human specimens in this study was obtained at the time of enrollment.

\section{Immunohistochemistry (IHC)}

Immunohistochemistry (IHC) analysis of human epidermal growth factor receptor (EGFR), cytokeratin 5/6 (CK5/6), mast/stem cell growth factor receptor (c-KIT or CD117) and Ki-67 was performed on formalin-fixed, paraffin-embedded breast cancer tissue. Tissue blocks were sectioned at 4- $\mu \mathrm{m}$ thickness and deparaffinized in xylene and rehydrated with graded ethanol. Heatinduced epitope retrieval in Tris/EDTA $\mathrm{pH} 9.0$ buffer was used for CK5/6, c-KIT and Ki-67 staining, while proteinase $\mathrm{K}$ enzymatic retrieval method was used for EGFR staining. All primary antibodies were supplied by Dako Corporation (Carpinteria, CA, USA). The dilution factors were as follows: EGFR (clone E30), 1:50; CK5/6 (clone D5/16 B4), 1:50; cKIT polyclonal, 1:400; and Ki-67 (clone MIB-1), 1:100. EGFR, CK5/6 or c-KIT positivity was defined as the presence of $1 \%$ or more positivelystained tumor cells as described previously $[8,19]$.

\section{Determination of proliferation indices}

To estimate the growth rate of tumors, the percentage of tumor cells expressing the proliferation marker Ki-67 was measured. A proliferation index was calculated for

Table 2 Summary of clinical pathologic status of non triple-negative cases (non-TNBC)

\begin{tabular}{|c|c|c|c|}
\hline \multirow[t]{2}{*}{ Characteristic } & \multicolumn{3}{|c|}{ No. of patients (\%) } \\
\hline & ER/PR+, HER2+ $(\mathrm{N}=111)$ & ER/PR+, HER2- $(\mathrm{N}=106)$ & ER/PR-, HER2+ $(\mathrm{N}=\mathbf{8 1})$ \\
\hline \multicolumn{4}{|l|}{ AGE AT DIAGNOSIS (y) } \\
\hline$\leq 40$ & $21(18.9 \%)$ & $17(16.0 \%)$ & $11(13.6 \%)$ \\
\hline $41 \leq y \leq 49$ & $42(37.8 \%)$ & $45(42.5 \%)$ & $26(32.1 \%)$ \\
\hline $50 \leq y \leq 65$ & $37(33.3 \%)$ & $33(31.1 \%)$ & $37(45.7 \%)$ \\
\hline$>65$ & $11(9.9 \%)$ & $11(10.4 \%)$ & $7(8.6 \%)$ \\
\hline \multicolumn{4}{|l|}{ HISTOLOGY } \\
\hline DCIS & $14(12.6 \%)$ & $13(12.3 \%)$ & $8(9.9 \%)$ \\
\hline IDC & 89 (80.2\%) & $74(69.8 \%)$ & 69 (85.2\%) \\
\hline Others & $8(7.2 \%)$ & $19(17.9 \%)$ & $4(4.9 \%)$ \\
\hline \multicolumn{4}{|l|}{ GRADE } \\
\hline 1 (well differentiated) & $2(1.8 \%)$ & $4(3.8 \%)$ & $1(1.2 \%)$ \\
\hline 2 (moderately differentiated) & $50(45.0 \%)$ & $48(45.3 \%)$ & $12(14.8 \%)$ \\
\hline 3 (poorly differentiated) & $52(46.8 \%)$ & $35(33.0 \%)$ & $64(79.0 \%)$ \\
\hline Not determined & $7(6.3 \%)$ & $19(17.9 \%)$ & $4(4.9 \%)$ \\
\hline \multicolumn{4}{|l|}{ TUMOR SIZE (cm) } \\
\hline$\leq 2$ & $46(41.4 \%)$ & $44(41.5 \%)$ & $19(23.5 \%)$ \\
\hline $2<\mathrm{cm} \leq 5$ & $32(28.8 \%)$ & $27(25.5 \%)$ & $40(49.4 \%)$ \\
\hline$>5$ & $7(6.3 \%)$ & $2(1.9 \%)$ & $6(7.4 \%)$ \\
\hline Not determined & $26(23.4 \%)$ & $33(31.1 \%)$ & $16(19.8 \%)$ \\
\hline \multicolumn{4}{|l|}{ LYMPH NODE INFILTRATION } \\
\hline Positive & $34(30.6 \%)$ & $24(22.6 \%)$ & $33(40.7 \%)$ \\
\hline Negative & 75 (67.6\%) & $74(69.8 \%)$ & $45(55.6 \%)$ \\
\hline Not determined & $2(1.8 \%)$ & $8(7.5 \%)$ & $3(3.7 \%)$ \\
\hline \multicolumn{4}{|l|}{ p53 STATUS } \\
\hline Positive & $10(9.0 \%)$ & $7(6.6 \%)$ & $28(34.6 \%)$ \\
\hline Negative & $101(91.0 \%)$ & 97 (91.5\%) & $53(65.4 \%)$ \\
\hline Not determined & $0(0.0 \%)$ & $2(1.9 \%)$ & $0(0.0 \%)$ \\
\hline
\end{tabular}

Note: Percentage (\%) indicates the percentage within the subgroup. DCIS ductal carcinoma in-situ, IDC invasive ductal carcinoma. 
each tumor lesion by counting the total number of tumor cell nuclear profiles and the number of Ki-67-positive nuclear profiles in randomly and systematically selected fields as described previously [20-22]. On average, 500 nuclear profiles were counted per tumor lesion.

\section{Statistical analysis}

The Fisher's exact test was used to analyze the correlation between the triple-negative phenotype and EGFR, CK5/6 or c-KIT expression. The Student's t-test and Mann-Whitney test was used to compare the $\mathrm{Ki}-67$ proliferaton index of TNBC and non-TNBC. All statistical analyses were performed using SPSS for Windows (Version 11). A $P$ value of less than 0.05 was considered statistically significant.

\section{Results}

Triple-negative breast cancer is associated with a younger age and high tumor grade in Malaysian women

A total of 340 breast cancer patient records obtained from the Gleneagles Hospital, Malaysia, from 2002 to 2006 were reviewed and analyzed. The majority of patients were middle aged between 41 and 65 years old, and had a mean age of $49.4 \pm 10.4$ years. The median age was 48 years. Most of the cases were invasive ductal carcinoma (IDC), accounting for $78.5 \%$ of all cases. The majority of these patients also presented with a grade 2 or 3 tumor. The tumor size had a mean of $2.6 \pm 1.4 \mathrm{~cm}$ and a median of $2.2 \mathrm{~cm}$. Lymph node infiltration and p53 expression were not common in this cohort of patients. The clinical pathological status of the investigated cohort is summarized in Table 1.

All cases were further stratified based on ER, PR and HER2 statuses. A total of 42 cases (12.4\%) were identified to be TNBC and the remaining 298 cases (87.6\%) expressed at least one of the markers and were classified as non-TNBC cases. Among all the non-TNBC cases, a total of $111(37.2 \%)$ cases were ER/PR + and HER2+, 106 (35.6\%) cases were ER/PR + and HER2-, and 81 (27.2\%) cases were ER/PR- and HER2+ (Table 2). Of note, the majority of patients diagnosed with TNBC were of a younger age (below 40 years) with a mean age of $45.3 \pm 10.3$ years versus $50.0 \pm 10.4$ years in the nonTNBC cases (Student's t-test, $P=0.0029$ ). In addition, most of the TNBC cases were high grade tumors with $76.2 \%$ of the cases diagnosed as grade 3 versus $50.7 \%$ in the non-TNBC group.

Although the tumor size from the TNBC cases were slightly larger $(2.8 \pm 1.6 \mathrm{~cm})$ compared to non-TNBC cases $(2.5 \pm 1.4 \mathrm{~cm})$, the difference, however, was not statistically significant (Student's t-test, $P=0.153$ ). Similarly, no differences in histology (IDC vs DCIS) (Fisher's exact test, $P=0.322$ ) and lymph node infiltration rate (Fisher's exact test, $P=0.177$ ) were observed between TNBC and
non-TNBC cases. Thus, the major differences between TNBC and non-TNBC were age and tumor grade, in which TNBC patients were younger and with high grade tumors compared to non-TNBC patients.

\section{Triple-negative breast cancer is strongly associated with} EGFR, CK5/6 and/or c-KIT expression

Based on the available clinical data, tissue samples from a total of 36 patients were reviewed and retrieved for EGFR, CK5/6 and c-KIT staining. Of the 36 samples, 18 were TNBC and 18 were non-TNBC based on the prior ER, PR and HER2 staining. All cases were age and grade matched as closely as possible and the majority was grade 3 tumors. The clinical pathological features of the cases included in the current study are summarized in Table 3.

Of all the TNBC cases, 61\% (11/18) were EGFR+, 72\% $(13 / 18)$ were CK5/6+ and $89 \%(16 / 18)$ were c-KIT+. In stark contrast, only $11 \%(2 / 18)$ were EGFR+, $6 \%(1 / 18)$ were CK5/6+ and $28 \%(5 / 18)$ were c-KIT + in the nonTNBC group (Figure 1 and Table 1). Furthermore, 56\% (10/18) of the TNBC cases were both EGFR + and CK5/6+, while none of the non-TNBC cases exhibited co-expression of these markers. Thus, EGFR, CK5/6 or c-KIT expression is strongly associated with TNBC in Malaysian women (Fisher's exact test, $P<0.01$ ) (Table 4 ).

Table 3 Summary of the clinical pathological status of TNBC and non-TNBC used for EGFR, CK5/6 and C-KIT immunohistochemical analysis

\begin{tabular}{|c|c|c|}
\hline \multirow[t]{2}{*}{ Characteristic } & \multicolumn{2}{|c|}{ No. of patients (\%) } \\
\hline & TNBC $(\mathrm{N}=18)$ & non-TNBC $(\mathrm{N}=18)$ \\
\hline \multicolumn{3}{|l|}{ AGE AT DIAGNOSIS $(y)$} \\
\hline$\leq 40$ & $3(16.6 \%)$ & $2(11.1 \%)$ \\
\hline $41 \leq y \leq 49$ & $10(55.5 \%)$ & $7(38.9 \%)$ \\
\hline $50 \leq y \leq 65$ & $5(27.7 \%)$ & $6(33.3 \%)$ \\
\hline$>65$ & $0(0.0 \%)$ & $3(16.7 \%)$ \\
\hline \multicolumn{3}{|l|}{ GRADE } \\
\hline 1 (well differentiated) & $0(0 \%)$ & $0(0 \%)$ \\
\hline 2 (moderately differentiated) & $3(16.6 \%)$ & $5(27.8 \%)$ \\
\hline 3 (poorly differentiated) & $15(83.3 \%)$ & $13(72.2 \%)$ \\
\hline \multicolumn{3}{|l|}{ TUMOR SIZE (cm) } \\
\hline$\leq 2$ & $7(38.9 \%)$ & $5(27.8 \%)$ \\
\hline $2<\mathrm{cm} \leq 5$ & $5(27.8 \%)$ & $9(50.0 \%)$ \\
\hline$>5$ & $3(16.7 \%)$ & $1(5.6 \%)$ \\
\hline Unknown & $3(16.7 \%)$ & $3(16.7 \%)$ \\
\hline \multicolumn{3}{|l|}{ LYMPH NODE INFILTRATION } \\
\hline Positive & $4(21.1 \%)$ & $8(44.4 \%)$ \\
\hline Negative & $14(77.8 \%)$ & $10(55.6 \%)$ \\
\hline
\end{tabular}

Note: Percentage (\%) indicates the percentage within the subgroup. 


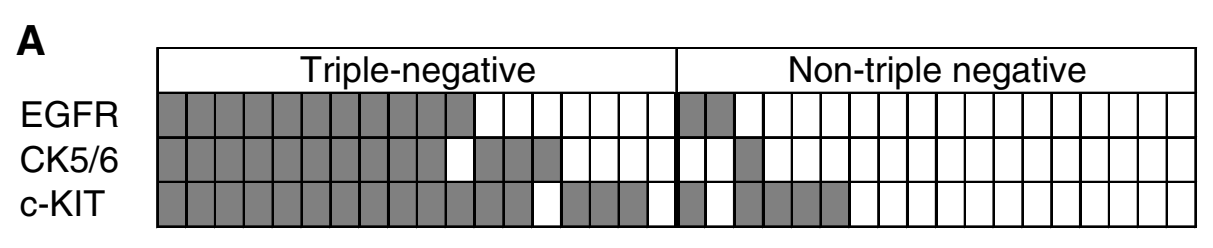

B

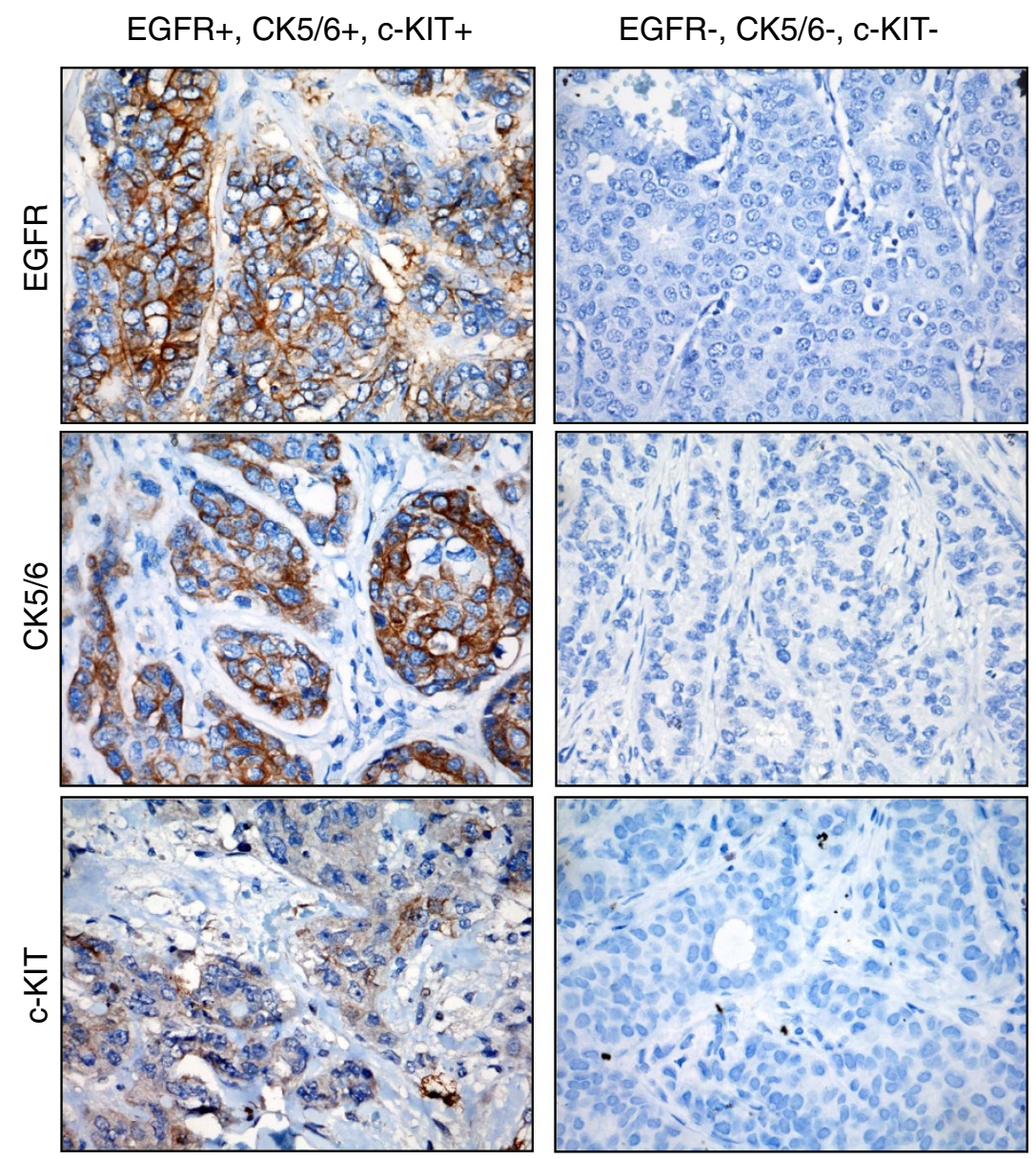

Figure 1 EGFR, CK5/6 and c-KIT expression is associated with TNBC. (A) A total of 18 TNBC and 18 non-TNBC were stained for EGFR, CK5/6 and C-KIT by IHC. (B) Representative immunostaining results for tumors that are EGFR, CK5/6 and c-KIT positive or negative.

Triple-negative breast cancers have higher Ki-67 indices

To further characterize the phenotypes of breast cancers in Malaysian women, we also analyzed the Ki-67 proliferation index in TNBC and non-TNBC cases in the current cohort. Thirty six out of 38 specimens (16 TNBC and 18 non-TNBC cases) were stained with a Ki-67-specific antibody (clone MIB-1) and the proliferation index was estimated as the percentage of Ki-67positive nuclear profiles in randomly and systematically selected fields. As shown in Figure 2, TNBC had a significantly higher Ki-67 index than non-TNBC tumors in Malaysian women (Student's t-test, $P=0.003$ and MannWhitey test, $P<0.004)$. The mean proliferation index for $\mathrm{TNBC}$ and non-TNBC tumors were $47.48 \pm 17.55$ and
$31.43 \pm 11.81$, respectively. The median proliferation index was 45.98 and 32.39 for TNBC and non-TNBC, respectively. These results suggest that TNBC has a higher proliferation rate than non-TNBC in Malaysian women.

\section{Discussion}

Breast cancer is a heterogeneous group of disease that can be characterized into clinically, morphologically and biologically distinct subgroups [14,23]. By gene expression profiling and IHC markers, breast cancers can be classified into five major subtypes: luminal A (ER + and/ or PR+, HER2-), luminal B (ER + and/or PR+, HER2+), HER2-overexpressing (ER-, PR-, HER2+), basal-like (ER-, PR-, HER2-, CK5/6+ and/or EGFR+) and normal breast- 
Table 4 Association of TNBC with EGFR, CK5/6 and/or c-KIT expression

\begin{tabular}{|c|c|c|c|}
\hline IHC Staining & TNBC (\%) & Non-TNBC (\%) & Fisher's exact test ( $P$ value) \\
\hline \multicolumn{4}{|l|}{ EGFR } \\
\hline Positive & $11(61.1 \%)$ & $2(11.1 \%)$ & $4.5 \times 10^{-5}$ \\
\hline Negative & 7 (38.9\%) & $16(88.9 \%)$ & \\
\hline \multicolumn{4}{|l|}{ CK 5/6 } \\
\hline Positive & $13(72.2 \%)$ & $1(5.6 \%)$ & $8.3 \times 10^{-3}$ \\
\hline Negative & $5(27.8 \%)$ & 17 (94.4\%) & \\
\hline \multicolumn{4}{|l|}{ c-KIT } \\
\hline Positive & $16(88.9 \%)$ & $5(27.8 \%)$ & $4.9 \times 10^{-5}$ \\
\hline Negative & $2(11.1 \%)$ & $13(72.2 \%)$ & \\
\hline \multicolumn{4}{|c|}{ EGFR and/or CK 5/6 } \\
\hline Positive & $14(77.8 \%)$ & $3(16.7 \%)$ & $6.1 \times 10^{-4}$ \\
\hline Negative & $4(22.2 \%)$ & $15(83.3 \%)$ & \\
\hline \multicolumn{4}{|c|}{ EGFR and/or CK $5 / 6$ or c-KIT } \\
\hline Positive & $17(94.4 \%)$ & $6(33.3 \%)$ & $3.0 \times 10^{-4}$ \\
\hline Negative & 1 (5.6\%) & 12 (66.7\%) & \\
\hline
\end{tabular}

like tumors $[1,8,12,24,25]$. Of particular importance is the basal-like subtype, which accounts for 15 to $20 \%$ of all breast cancers and confers a markedly poor prognosis $[1,4,5]$. Recent studies have shown that basal-like breast cancers are likely to be mitotically active high-grade invasive tumors that are associated with a younger patient age $[4,26,27]$. A population-based study also identified this subtype to be more prevalent in premenopausal African American women and highly associated with
BRCA-1 mutation $[4,12,26,27]$. Due to their lack of ER, PR and HER2 expression, basal-like breast cancers are also unlikely to respond to anti-estrogen hormonal therapies or trastuzumab [26,28].

To date, the gold standard for identifying basal-like breast cancers is based on gene expression profiling. However, cost and technical issues have rendered gene expression profiling impractical as a routine diagnostic tool in the clinical setting. In the Western population,

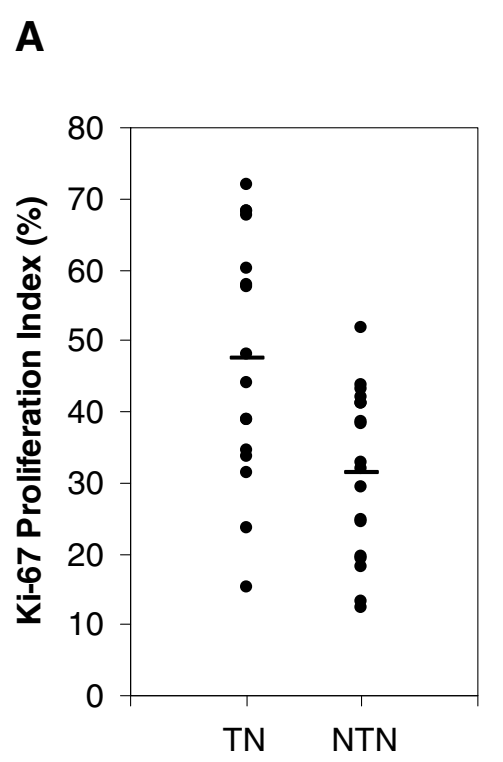

B

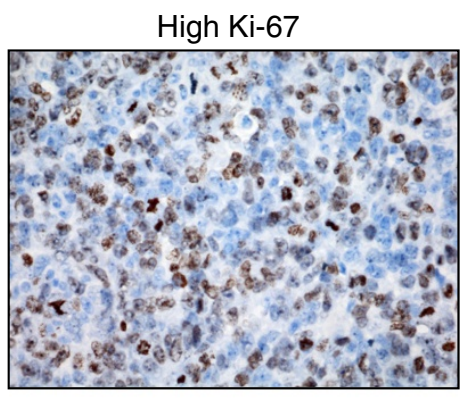

Low Ki-67

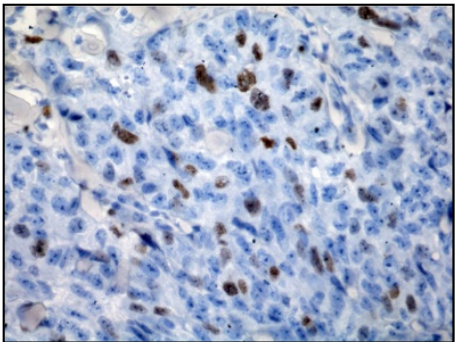

Figure 2 TNBC has a higher growth rate. (A) Ki-67 proliferation index was used to estimate the growth rate of tumors (16 TNBC and 18 nonTNBC). , Ki-67 proliferation index of each tumor; - , the median Ki-67 proliferation index in the TNBC and non-TNBC subgroup. On average, 500 nuclear profiles were counted per tumor lesion. (B) Representative immunostaining of tumors that have a high or low Ki-67 proliferation index. 
approximately 70 to $90 \%$ of "triple-negative" breast cancers (ER-, PR-, HER2-) express basal markers, resulting in the triple-negative subtype commonly used as a surrogate marker for the basal-like subtype [1,4,8,18,29-37]. Relatively little is known about this disease entity within Asian populations, and in particular Malaysian populations.

Within the small cohort of 340 breast cancer patients described in this study, a total of 42 cases $(12.4 \%)$ were identified as triple-negative. This proportion was slightly lower than the recent studies in the Malaysian, Japanese, Chinese and Korean populations that estimated the prevalence of TNBC to be around 15 to 20\% [23,38-41]. Consistent with earlier studies, our results showed that TNBC in Malaysian women was strongly associated with a younger age and high grade tumors compared to nonTNBC $[5,10,14,15,38,42]$. However, no significant differences in tumor size, histology (IDC vs DCIS) and lymph node infiltration rates were observed between TNBC and non-TNBC in the current study.

Further analysis was carried out to investigate the expression of EGFR, CK5/6 and c-KIT in TNBC and nonTNBC specimens. Due to the lack of information on HER2 amplification, only tumors with HER2 scores of 0 were included in the TNBC cohort. Our results demonstrated that TNBC in Malaysian women was strongly associated with EGFR, CK5/6 and c-KIT expression. Our results also showed that TNBC had a significantly higher Ki-67 proliferation index than non-TNBC, suggesting that TNBC could be more progressive.

Numerous studies have also shown that basal-like breast cancer can be specifically identified using IHC surrogate panels including ER, PR and HER2 negativity and either EGFR or CK5/6 positivity (ER-, PR-, HER2-, CK5/6+ and/or EGFR+) $[8,19,26,43,44]$. Using such surrogates, our study showed that $78 \%(14 / 18)$ of TNBC can be categorized as basal-like breast cancers. This proportion is consistent with previous studies that also show that $71.5 \%$ of TNBC are basal-like by gene expression profiling [30].

\section{Conclusions}

In conclusion, the incidence of TNBC in this small cohort, predominantly Asian population, is comparable to reported data in other populations. Consistent with other studies, TNBC in Malaysian women is associated with a younger age and higher grade of tumor, as well as p53 expression in bivariate analysis. Our findings also confirm that TNBC in Malaysian women strongly correlates with EGFR, CK5/6 and c-KIT expression, and have a higher proliferation rate.

\section{Competing interests}

The authors declare that they have no competing interests.

\section{Authors' contributions}

SKKP carried out the IHC staining and data analysis. AT and SN participated in data acquisition and interpretation, and critically revising the manuscript. LCO conceived of the study, and participated in its design and coordination. All authors read and approved the final manuscript.

\section{Acknowledgements}

This work was supported by the International Medical University (IMU) Research Fund (to COL and AT) and by the IMU BMedSci Research Training Program (to SKKP).

\section{Author details}

${ }^{1}$ School of Medicine, International Medical University, Bukit Jalil, Kuala Lumpur 57000, Malaysia. ${ }^{2}$ Gleneagles Hospital Kuala Lumpur, 282 \& 286 Jalan Ampang, Kuala Lumpur 50450, Malaysia. ${ }^{3}$ School of Pharmacy and Health Sciences, International Medical University, Bukit Jalil, Kuala Lumpur 57000, Malaysia. ${ }^{4}$ International Medical University, 126 Jalan 19/155B, Bukit Jalil, Kuala Lumpur 57000, Malaysia.

Received: 15 December 2011 Accepted: 24 September 2012 Published: 26 September 2012

\section{References}

1. Sorlie T, Perou CM, Tibshirani R, Aas T, Geisler S, Johnsen H, Hastie T, Eisen $M B$, van de Rijn M, Jeffrey SS, et al: Gene expression patterns of breast carcinomas distinguish tumor subclasses with clinical implications. Proc Natl Acad Sci U S A 2001, 98(19):10869-10874.

2. Loi S, Piccart M, Sotiriou C: The use of gene-expression profiling to better understand the clinical heterogeneity of estrogen receptor positive breast cancers and tamoxifen response. Crit Rev Oncol Hematol 2007, 61(3):187-194.

3. van de Vijver MJ, He YD, van't Veer $L$, Dai H, Hart AA, Voskuil DW, Schreiber GJ, Peterse JL, Roberts C, Marton MJ, et al: A gene-expression signature as a predictor of survival in breast cancer. N Engl J Med 2002, 347(25):1999-2009.

4. Sorlie T, Tibshirani R, Parker J, Hastie T, Marron JS, Nobel A, Deng S, Johnsen $H$, Pesich R, Geisler S, et al: Repeated observation of breast tumor subtypes in independent gene expression data sets. Proc Natl Acad Sci U S A 2003, 100(14):8418-8423.

5. Sotiriou C, Piccart MJ: Taking gene-expression profiling to the clinic: when will molecular signatures become relevant to patient care? Nat Rev Cancer 2007, 7(7):545-553.

6. Leong CO, Vidnovic N, DeYoung MP, Sgroi D, Ellisen LW: The p63/p73 network mediates chemosensitivity to cisplatin in a biologically defined subset of primary breast cancers. J Clin Invest 2007, 117(5):1370-1380.

7. Lim LY, Vidnovic N, Ellisen LW, Leong CO: Mutant p53 mediates survival of breast cancer cells. Br J Cancer 2009, 101(9):1606-1612.

8. Nielsen TO, Hsu FD, Jensen K, Cheang M, Karaca G, Hu Z, HernandezBoussard T, Livasy C, Cowan D, Dressler L, et al: Immunohistochemical and clinical characterization of the basal-like subtype of invasive breast carcinoma. Clin Cancer Res 2004, 10(16):5367-5374.

9. Reis-Filho JS, Tutt AN: Triple negative tumours: a critical review. Histopathology 2008, 52(1):108-118.

10. Rouzier R, Perou CM, Symmans WF, Ibrahim N, Cristofanilli M, Anderson K, Hess KR, Stec J, Ayers M, Wagner P, et al: Breast cancer molecular subtypes respond differently to preoperative chemotherapy. Clin Cancer Res 2005, 11(16):5678-5685.

11. Lund MJ, Trivers KF, Porter PL, Coates RJ, Leyland-Jones B, Brawley OW, Flagg EW, O'Regan RM, Gabram SG, Eley JW: Race and triple negative threats to breast cancer survival: a population-based study in Atlanta, GA. Breast Cancer Res Treat 2009, 113(2):357-370.

12. Carey LA, Perou CM, Livasy CA, Dressler LG, Cowan D, Conway K, Karaca G, Troester MA, Tse CK, Edmiston S, et al: Race, breast cancer subtypes, and survival in the Carolina breast cancer study. JAMA 2006, 295(21):2492-2502.

13. Cunningham JE, Montero AJ, Garrett-Mayer E, Berkel HJ, Ely B: Racial differences in the incidence of breast cancer subtypes defined by combined histologic grade and hormone receptor status. Cancer Causes Control 2009, 21(3):399-409. 
14. Thike AA, Cheok PY, Jara-Lazaro AR, Tan B, Tan P, Tan PH: Triple-negative breast cancer: clinicopathological characteristics and relationship with basal-like breast cancer. Mod Pathol 2009, 23(1):123-133.

15. Kim MJ, Ro JY, Ahn SH, Kim HH, Kim SB, Gong G: Clinicopathologic significance of the basal-like subtype of breast cancer: a comparison with hormone receptor and Her2/neu-overexpressing phenotypes. Hum Pathol 2006, 37(9):1217-1226.

16. Silver DP, Richardson AL, Eklund AC, Wang ZC, Szallasi Z, Li Q, Juul N, Leong CO, Calogrias D, Buraimoh A, et al: Efficacy of neoadjuvant Cisplatin in triple-negative breast cancer. J Clin Oncol 2010, 28(7):1145-1153.

17. Lamy PJ, Fina F, Bascoul-Mollevi C, Laberenne AC, Martin PM, Ouafik L, Jacot W: Quantification and clinical relevance of gene amplification at chromosome 17q12-q21 in human epidermal growth factor receptor 2-amplified breast cancers. Breast Cancer Res 2012, 13(1):R15.

18. Sauter G, Lee J, Bartlett JM, Slamon DJ, Press MF: Guidelines for human epidermal growth factor receptor 2 testing: biologic and methodologic considerations. J Clin Oncol 2009, 27(8):1323-1333.

19. Livasy CA, Karaca G, Nanda R, Tretiakova MS, Olopade OI, Moore DT, Perou CM: Phenotypic evaluation of the basal-like subtype of invasive breast carcinoma. Mod Pathol 2006, 19(2):264-271.

20. Aleskandarany MA, Rakha EA, Macmillan RD, Powe DG, Ellis IO, Green AR: MIB1/Ki-67 labelling index can classify grade 2 breast cancer into two clinically distinct subgroups. Breast Cancer Res Treat 2010, 127(3):591-599.

21. Weidner N, Moore DH 2nd, Vartanian R: Correlation of Ki-67 antigen expression with mitotic figure index and tumor grade in breast carcinomas using the novel "paraffin"-reactive MIB1 antibody. Hum Pathol 1994, 25(4):337-342.

22. Jalava P, Kuopio T, Juntti-Patinen L, Kotkansalo T, Kronqvist P, Collan Y: Ki67 immunohistochemistry: a valuable marker in prognostication but with a risk of misclassification: proliferation subgroups formed based on Ki67 immunoreactivity and standardized mitotic index. Histopathology 2006, 48(6):674-682

23. Rhee J, Han SW, Oh DY, Kim JH, Im SA, Han W, Park IA, Noh DY, Bang YJ, Kim TY: The clinicopathologic characteristics and prognostic significance of triple-negativity in node-negative breast cancer. BMC Cancer 2008, 8:307.

24. Perou CM, Sorlie T, Eisen MB, van de Rijn M, Jeffrey SS, Rees CA, Pollack JR, Ross DT, Johnsen H, Akslen LA, et al: Molecular portraits of human breast tumours. Nature 2000, 406(6797):747-752.

25. Rakha EA, Aleskandarany M, El-Sayed ME, Blamey RW, Elston CW, Ellis IO, Lee $\mathrm{AH}$ : The prognostic significance of inflammation and medullary histological type in invasive carcinoma of the breast. Eur J Cancer 2009, 45(10):1780-1787.

26. Cheang MC, Voduc D, Bajdik C, Leung S, McKinney S, Chia SK, Perou CM, Nielsen TO: Basal-like breast cancer defined by five biomarkers has superior prognostic value than triple-negative phenotype. Clin Cancer Res 2008, 14(5):1368-1376.

27. Turner N, Tutt A, Ashworth A: Hallmarks of 'BRCAness' in sporadic cancers. Nat Rev Cancer 2004, 4(10):814-819.

28. Slamon DJ, Leyland-Jones B, Shak S, Fuchs H, Paton V, Bajamonde A Fleming T, Eiermann W, Wolter J, Pegram M, et al: Use of chemotherapy plus a monoclonal antibody against HER2 for metastatic breast cancer that overexpresses HER2. N Engl J Med 2001, 344(11):783-792.

29. Kwan ML, Kushi LH, Weltzien E, Maring B, Kutner SE, Fulton RS, Lee MM, Ambrosone CB, Caan BJ: Epidemiology of breast cancer subtypes in two prospective cohort studies of breast cancer survivors. Breast Cancer Res 2009, 11(3):R31.

30. Bertucci F, Finetti $P$, Cervera N, Esterni B, Hermitte F, Viens P, Birnbaum D: How basal are triple-negative breast cancers? Int J Cancer 2008, 123(1):236-240

31. Bidard FC, Conforti R, Boulet T, Michiels S, Delaloge S, Andre F: Does triplenegative phenotype accurately identify basal-like tumour? An immunohistochemical analysis based on 143 'triple-negative' breast cancers. Ann Oncol 2007, 18(7):1285-1286.

32. Bauer KR, Brown M, Cress RD, Parise CA, Caggiano V: Descriptive analysis of estrogen receptor (ER)-negative, progesterone receptor (PR)-negative, and HER2-negative invasive breast cancer, the so-called triple-negative phenotype: a population-based study from the California cancer Registry. Cancer 2007, 109(9):1721-1728.

33. Carey LA, Dees EC, Sawyer L, Gatti L, Moore DT, Collichio F, Ollila DW, Sartor $\mathrm{Cl}$, Graham ML, Perou CM: The triple negative paradox: primary tumor chemosensitivity of breast cancer subtypes. Clin Cancer Res 2007, 13(8):2329-2334.

34. Cleator S, Heller W, Coombes RC: Triple-negative breast cancer: therapeutic options. Lancet Oncol 2007, 8(3):235-244.

35. Dent R, Trudeau M, Pritchard KI, Hanna WM, Kahn HK, Sawka CA, Lickley LA, Rawlinson E, Sun P, Narod SA: Triple-negative breast cancer: clinical features and patterns of recurrence. Clin Cancer Res 2007, 13(15 Pt 1):4429-4434.

36. Haffty BG, Yang Q, Reiss M, Kearney T, Higgins SA, Weidhaas J, Harris L, Hait W, Toppmeyer D: Locoregional relapse and distant metastasis in conservatively managed triple negative early-stage breast cancer. J Clin Oncol 2006, 24(36):5652-5657.

37. Rakha EA, El-Sayed ME, Green AR, Lee AH, Robertson JF, Ellis IO: Prognostic markers in triple-negative breast cancer. Cancer 2007, 109(1):25-32.

38. Tan GH, Taib NA, Choo WY, Teo SH, Yip CH: Clinical characteristics of triple-negative breast cancer: experience in an Asian developing country. Asian Pac J Cancer Prev 2009, 10(3):395-398.

39. Teoh KH, Looi LM, Sabaratnam S, Cheah PL, Nazarina AR, Mun KS: An analysis of predictive biomarkers in routine histopathological reporting of infiltrating ductal breast carcinoma in a tertiary hospital in Malaysia with a focus on limitations and directions for future development. Malays J Pathol 2011, 33(1):35-42.

40. Iwase H, Kurebayashi J, Tsuda H, Ohta T, Kurosumi M, Miyamoto K, Yamamoto Y, Iwase T: Clinicopathological analyses of triple negative breast cancer using surveillance data from the registration committee of the Japanese breast cancer society. Breast Cancer 2009, 17(2):118-124.

41. Tian XS, Cong MH, Zhou WH, Zhu J, Chen YZ, Liu Q: Clinicopathologic and prognostic characteristics of triple-negative breast cancer. Onkologie 2008, 31(11):610-614.

42. Brenton JD, Carey LA, Ahmed AA, Caldas C: Molecular classification and molecular forecasting of breast cancer: ready for clinical application? J Clin Oncol 2005, 23(29):7350-7360.

43. Kreike $B$, van Kouwenhove $M$, Horlings $H$, Weigelt B, Peterse $H$, Bartelink $H$, van de Vijver MJ: Gene expression profiling and histopathological characterization of triple-negative/basal-like breast carcinomas. Breast Cancer Res 2007, 9(5):R65.

44. Lachapelle J, Foulkes WD: Triple-negative and basal-like breast cancer: implications for oncologists. Curr Oncol 2011, 18(4):161-164.

doi:10.1186/1472-6890-12-18

Cite this article as: Kanapathy Pillai et al:: Triple-negative breast cancer is associated with EGFR, CK5/6 and c-KIT expression in Malaysian women. BMC Clinical Pathology 2012 12:18.

\section{Submit your next manuscript to BioMed Central and take full advantage of:}

- Convenient online submission

- Thorough peer review

- No space constraints or color figure charges

- Immediate publication on acceptance

- Inclusion in PubMed, CAS, Scopus and Google Scholar

- Research which is freely available for redistribution 